\title{
Economic convergence and polarisation: towards a multi-dimensional approach
}

\author{
József BENEDEK ${ }^{1}$ and Aura MOLDOVAN ${ }^{1}$
}

\begin{abstract}
The current increase of regional inequalities in Europe, and in particular in Central and Eastern Europe (CEE) has led to the reconsideration and revival of the concepts of "polarisation" and "convergence" in academic fields like regional economics, economic geography and spatial planning as well. In contrast to the classical view on these concepts determined by functionalism and topology, the new theoretical and empirical perspectives are emphasising a multidimensional perspective. In addition, there is an important debate about the relation between economic inequalities and growth. This article provides a critical overview and assessment of the theoretical and empirical work on regional inequalities with special emphasis on theories of economic and social polarisation, regional economic growth, convergence, and social inequalities. We attempt to combine two powerful concepts of polarisation and convergence, emphasising their relational and multi-scalar nature. Building on this basis, we propose a multidimensional concept of socio-economic polarisation, which comprises processes of convergence and divergence, growth and mobility in economic and social dimensions.
\end{abstract}

Keywords: regional inequalities, economic convergence, polarisation, Central and Eastern Europe

\section{Introduction}

In the last decades we have experienced a general growing tendency of regional inequalities. However, the views on the intensity and direction of regional inequalities differ widely from one author to another, depending on the scale, timeframe and methodology of the analysis. In Europe the majority of the authors seem to agree that while the disparities of national economies decreased in the last decades, sub-national economic inequalities have been increasing. Such processes were fuelled by the rapidly growing metropolises and national capitals (London, Paris, Brussels, Vienna, Prague, Bratislava, Bucharest etc.) and the parallel peripheralisation of rural and old industrial regions. In addition, the financial crisis has stopped the decreasing tendency of regional inequalities between Member States from 2008 on.
The Cohesion Reports of the European Commission (EC) have clearly indicated these polarisation and peripheralisation tendencies at sub-national level and proposed the strengthening of territorial cohesion by guiding one third of the EU budget to the reduction of economic and social disparities in 2014-2020 (EC 2004, 2007, 2010, 2014). However, despite this consensus, there is still a confusion resulted by the employment of the different concepts used in the quantitative studies of mainstream economic and regional science (convergence/divergence) and in qualitative approaches applied in economic geography, spatial planning and sociology (centralisation/peripheralisation, polarisation, marginalisation).

This paper offers a critical review of different theoretical concepts focusing on regional inequalities. We have selected theories and concepts relevant to the convergence/diver-

\footnotetext{
${ }^{1}$ Hungarian Department of Geography, Faculty of Geography, Babeş-Bolyai University, RO-400006 Cluj-Napoca, Str. Clinicilor 5. E-mail: jozsef@geografie.ubbcluj.ro
} 
gence and polarisation debates ${ }^{2}$. The neoclassical and the new theories of growth are considered as the mainstream approaches in this field, thus, main statements and developments must be discussed here. Historical polarisation and sociological theories - more 'heterodox' in content and methods, and marginal in the field of economics - shall also be discussed below to deliver important arguments towards the development of a multiscalar and multi-dimensional approach on regional inequalities.

Our paper is focused on the connection of polarisation and the socio-economic processes of differentiation. Drawing on a literature survey, we summarise the facts of the main theoretical and empirical approaches discussing the problems of convergence and spatial polarisation in the first section. In the second, we propose a multidimensional concept of polarisation and convergence, which comprises economic and social dimensions. We conclude with our final remarks and with prospects for further research in the third section.

\section{Economic growth, convergence and polarisation: theoretical approaches}

Core-periphery structures in economics have always been defined as process-centred, unlike approaches in economic and urban geography that employed a traditional definition that is rather location-oriented and static and where the new process-oriented perspective offered by introducing the term "peripherialisation" (LANG, T. 2012; KüHN, M. 2015) seems to be a promising innovation.

\footnotetext{
${ }^{2}$ The research leading to these results was conducted in the frame of the project "Socio-economic and Political Responses to Regional Polarisation in Central and Eastern Europe" (RegPol $\left.{ }^{2}\right)$, coordinated by the Leibniz Institute for Regional Geography, Leipzig/Germany. The project received funding from the People Programme (Marie Curie Actions) of the European Union's Seventh Framework Programme FP7/2007-2013/ under REA grant agreement no 607022
}

The basic position of mainstream economics is that, regional inequalities relate strongly to economic growth. Therefore, the main focus of the economic literature related to regional inequalities is whether economic growth produces increasing or decreasing inequalities. Furthermore, the economists rely on the so-called convergence-studies as analytical approaches to understand the relations between growth and inequalities.

Apart from the question, whether economic growth leads to an increase or decrease of socio-spatial inequalities, three other important issues are related to the above-mentioned concepts:

- First, taking into account the important regional variability of economic growth, how can the different economic growth rates between regions be explained?

- Second, how important is the spatial context for these differences?

- Third, what are the consequences of the spatially differentiated economic growth for spatial policy, or more explicitly, which are the recommendations for regional policy in order to diminish regional inequalities and increase territorial cohesion?

In the following subsections several theoretical approaches will be summarised and critically evaluated to reveal, how these basic concepts contribute to the understanding of regional inequalities. We discuss traditional approaches on growth and convergence (the neoclassical exogenous growth theory, the post-Keynesian theories, and the export base theory, as laid out in the 1950s), as well as contributions from economic historians and more heterodox approaches (economic and spatial polarisation approach; sociological approaches on inequalities). These are followed by an account of the most recent theoretical developments (new economic geography, new growth theory) and by an overview of the recent empirical work on convergence.

The selection of literature is not meant to be exhaustive. It focuses on widely cited concepts and their selection was inspired by the works of Schätzl, L. (1998), BENEdeK, J. (2004) and KüHN, M. (2015). We have summarised the 
main statements of the analysed approaches, evaluated according to the following key questions: how the development of inequalities is explained and what tendency for the evolution of regional inequalities is expected.

\section{Traditional models of economic growth}

Studies on economic convergence are rooted in the neoclassical theory of economic growth. The dominant concept between 1950 and 1980 was the Solow-model of exogenous growth, where the output is determined by three factors: capital, labour and technological progress (SoLow, R.M. 1956). Technology is assumed to be a public good, while technological progress (including advances in basic science) is assumed to be exogenous. This means that technological progress has the same contribution to economic growth in all regions, leading to the assumption that GDP per capita should grow at the same rate in all regions (FAGERBERG, J. 1995).

Nevertheless, due to the different regional initial conditions and, accordingly, to the different regional capital-labour ratios, poorer regions (with low capital-labour ratio) are growing faster than the richer ones, thus, regional inequalities tend to decrease and finally, should disappear. The model offers a simple explanation for the evolution of regional inequalities: under the assumption of constant returns to capital, once a region achieves its steady-state as a result of longterm development, it will grow at the rate of technological progress. The farther is the region from its steady-state, the larger its growth rate of GDP per capita can be. As a consequence, poor regions will tend to grow faster than richer ones, which could result in income convergence (Solow, R.M. 1956; Mankiw, N.G. et al. 1992). In this model, convergence is determined by the capital flows directed from regions where it is abundant to regions where it is scarce, in order to achieve the highest rate of profit on capital.

One of the weak points of the neoclassical growth theory comes from the fact that it is not concerned with regional differences in the use of production factors and in the organisation of firms. Another weak point is the assumption on the free flow of production factors that is refuted by empirical facts. For example, a major share of capital transfers and foreign direct investments are taking place between advanced economies (Schatz, A.J. and Venables, A.J. 2000). Moreover, the labour has no unlimited mobility due to the high living costs, the differences in social and cultural environments, the accessibility of jobs etc.

Under these circumstances regional inequalities between rich and poor regions can not diminish. In addition, empirical work has proved that capital and labour costs explain only a small part of actual growth (FAGERBERG, J. 1995). As a consequence, the equalisation of inter-regional inequalities as stated in the neoclassical theory is not confirmed by the empirical results, being thus less adequate in explaining regional inequalities.

Keynes' theory focused on demand and on state interventions, considered investments as a key factor for economic development, and did not address the question of convergence directly. The latter problem is discussed explicitly in the post-Keynesian theory such as in the Harrod-Domar model relying on the assumption that the import determines the growth of regional economies (HARROD, R.F. 1939; Domar, E.D. 1946). Regional investments exercise three types of effects on growth (SсHÄTzL, L. 1998), such as income effects, capacity effects (increasing production capacities and increasing capital stock) and complementarity effects (forward linkage effects on the suppliers' sector and backward linkage effects on the consumption).

The theory suggests that equilibrated growth occurs when the demand growth has the same intensity as the growth of production capacity, reflected through income and capacity effects. All these effects contain a spatial component: capacity effects generated by investments are connected to a location, their spatial distribution and characteristics being linked to the factors determining the spatial distribution of investments. The in- 
come effects and the complementarity effects are spatially diffuse, being more intensive in the place of investment and decreasing with the distance from the place of investment.

The export base theory represents a variety of Keynesian growth theories. It concentrates accordingly on the demand side, more exactly - unlike the former one - it focuses on the external demand (NorTH, D. 1955). The key argument is that the export activities realised in one region generate a cumulative regional development process. The size and time persistency of external demand for certain products or services determines the regional growth via multiplier effects, while a declining export demand generates the decline of the whole region (MALECKI, E.J. 1997). One of the weak points of this theory lies in its methodology: it distinguishes basic and export oriented activities and sectors, thus, calls for a very detailed and not always accessible statistics. In addition, the above-mentioned differentiation is highly dependent on the size and delimitation of the region. Another constraint is related to the urban economies, which are realising an intense internal commerce, the export sectors having a lower share.

The theory induces a major reduction by the exclusive focus on the export activities, neglecting important internal growth factors like the increase of the internal consumption, the change of the consumption function, endogenous technological development etc. (SсHÄTZL, L. 1998).

\section{The sociological approaches on inequalities}

Social theories in sociological approach have long been considered with inequalities, looking at how various resources are being distributed within a society (EAPN 2014) and also at the resulting social differences between various groups. Social inequality in this sense can be found wherever the accessibility of social goods and powerful positions are systematically restricted, thereby favouring or impairing the lives of the affected in- dividuals or groups. Inequalities manifesting e.g. in limited access to occupational, educational and financial opportunities might lead to social exclusion and marginalisation.

At the same time, exclusion from social networks of power - having little to no chance for influencing the decisions affecting daily lives - also contributes to such marginalisation. Indicators used to measure social inequality and marginalisation empirically can be assigned to one of four interconnected dimensions: wealth, knowledge, organisation (understood as the status of a profession within an organisational hierarchy) and association (or social capital) (KRECKEL, R 2004). This means - very broadly - that socially marginalised groups are characterised by low income, a low level of education, a high level of unemployment and no access to power holding social networks.

It is important to note that all these four dimensions are mutually dependent and each one explores a significant side of the structural heterogeneity, which is determining the distribution of resources. However, one dimension is being emphasized for the purpose of capturing inequalities, and that is wealth - or, indicating the lack of wealth, poverty (KüHN, M. 2015).

In the EU social policy inequality is analysed mainly through the distribution of income. Moreover, non-financial assets (such as property, shares or investment, especially, housing) are increasingly considered while analysing the wealth of households (EAPN 2014; MaesrTI, V. 2015). Nevertheless, sociological studies are concerned mostly with social relations that individuals, households and groups are embedded in and which shape the patterns of social inequality (KRECKel, R. 2004).

More complex studies on social inequality and social exclusion supported by the EU also include non-financial indicators such as life expectancy at birth, access to services (education, health and housing), old age dependency, share of foreign-born population, nutrition and sustainability (Copus, A. 2014; THIRY, G. 2015). 
In order to link social inequality to the peripheralisation discourse, it is helpful to consider KRECKEL's conceptualisation of peripherality (2004) as a structurally embedded constellation of conditions, which results in limited access to generally available and desirable resources (material or symbolic) for the people and groups affected, leaving a restricted room for autonomous action to them. In our interpretation, the difference between marginalisation and peripheralisation is the following: the first term refers to sociostructural exclusion, to pushing a group of people to the edge of social hierarchy, while we consider the second as the socio-spatial dimension of the process. Peripheralisation, thus, can be described as the gradual decline in socio-spatial development in relation to the dominant centre (KeIM, K.D. 2006).

The importance of the spatial dimension for social inequality is acknowledged also by EU social policy. One of the key factors used by EU policy-makers to determine which groups of people are at risk of living in poverty is "living in a remote or disadvantaged community where access to services is worse" (EAPN 2014, p. 32). The structural disadvantages that people in peripheries face are limiting their capacity to improve their situation and raises the risk of falling into a vicious circle: given the lack of services including educational facilities, and the limited choices of career paths in peripheral areas, those who have resources for migration will leave, further diminishing the human capital and the chances of change in the region they leave behind (MAssEy, D. 1990). Moreover, apart from the actual lack of physical and social infrastructures, the inhabitants of marginalized places have to deal with the negative effects the image of backwardness, spread "from above", through political, popular and scientific discourses, as well as "from below", through daily routines and interactions (WACQUANT, L. 2007).

Uneven development has always been a major theme in social theory. Famously, Karl MARx compared the level of development between societies, looking at the modes of production at a national scale. His interpretation of the law of capitalist accumulation includes the criticism that any emergence of wealth and capital concentration goes together with poverty and oppression. Moreover, MARX views uneven development as intrinsically linked to the transition from one mode of production to another: as an old mode declines and a new, more progressive one rises, different growth patterns are created, resulting in uneven development (Bond, P. 1999).

Developing the Marxist approach by adding a spatial component explicitly, David Harvey (1996) sees the increasing inequalities in development as a result of the competition between different places for attracting investments. In this process, the differentiated return on investment creates or destroys certain spatial and class configurations - on a local, regional and national scale (Bond, P. 1999). Depending on how successful they are in attracting investments and capital, the spaces described by Harvey enter core-periphery (dependent) relations with each other, as LANG, T. et al. (2015) argued. Moreover, Henri LefÈbvre (1991) linked uneven spatial development specifically to real estate investments, through which, inequalities in capital accumulation are transposed into space (residential patterns; unequal provision of urban services).

While neither poverty nor inequality are bound to certain physical spaces and can be found in all types of societies, sociological studies have a strong urban bias (GoTTDIENER, M. and BudD, L. 2005). The inequalities within cities have been increasing since the 1980s, due to suburbanisation processes and the resulting concentration of poverty in the central urban areas. Nevertheless, sociological studies are also concerned with global interconnectedness of countries and cities and the uneven development within the global labour market that resulted in the rise of major cities as high command centres.

The process produced an increasing power concentrated in central urban areas on the one hand, and the expansion of commercial spaces dispersed across space on the other 
(Gottdiener, M. and Budd, L. 2005, p. 73). SASSEN, S. (1991) considers these major cities as 'global' ones, and describes their rise as hosting processes of growing polarisation in terms of occupational and income structures.

A very similar image, focused on the polarised occupational structure within global cities, is described by Mollenkopf, J. and Castells, M. (1991). Each of the cited scholars is concerned with migration flows that play a crucial role in enabling this process of polarisation due to the expansion of lowskilled and poorly paid jobs occupied by immigrant workers in global cities.

However, the above concepts have been criticised for employing unstable, value-laden concepts and for oversimplifying the empirical reality by reducing it to a simple dichotomy. Hamnetт, C. (2001) argued that the phenomenon described by SASSEN in global cities is rather caused by professionalisation, typical of post-industrial societies than polarisation. Moreover, shifting the focus from individuals (as SASSEN discussed it) to households might produce a clearer image of the occupational structure in global cities, as it would shed light upon the increasing inequality between households (work-poor and work-rich households), as it was argued by HamnetT.

The household focus might also support the shift from the dichotomic view of polarisation processes (command centre vs. production periphery) towards a deeper (multidimensional) understanding of this socio-spatial phenomenon (GotTdiener, M. and BudD, L. 2005. p. 66).

What all these sociological theorists have in common is that they have a critical view on inequality and stratification, and consider them as the results of the modern capitalist relations of exploitation and exclusion in which, some individuals or social groups benefit at the expense of others. In capitalist societies, the differences between cores and peripheries is seen as the result of capital investments, concentrated in urban and suburban settlements, where the rate of return is the highest. The investment sets off a cumulative effect, creating jobs and generating tax revenues, enabling public investments to better infrastructure and the quality of life. The resulting highly differentiated life chances of the respective residents support the reproduction and the enhancement of socio-spatial inequalities (GotTdiener, M. and BudD, L. 2005). The argument continues by considering the forms of social inequalities typical of modernity and capitalism, shaped not by the independent achievements of individuals or social groups, but by their ascribed characteristics. Thus, inequalities are considered to be persisting at various scales, while the gap between rich and poor is deepening (Korzeniewicz, R.P. and Albrecht, S. 2013).

The general weakness of the sociological approach to inequalities lies in the vague definition of the concepts of core and periphery (KüHN, M. 2015). This also means that the identification of spatial core-periphery structures, at any scale, remains a subjective matter. Even though, sociologists have focused on the inequalities in cities, we agree with KüHN (2015) on that the poverty concept can easily be transferred to regional scale: if a large number of households or municipalities experiencing poverty are concentrated in a particular area, it should be considered as a periphery at regional scale Such peripheries are the results of deindustrialisation, ageing and demographic shrinkage, lack of investment, low level of income and out-migration of higher educated and young people (KüHN, M. 2015).

\section{Historical approaches}

Historical approaches embrace all contributions of economic history to studying economic development and growth. The theories elaborated on this ground advanced the idea of the multi-stage and linear economic development path (Gerschenkron, A. 1962). One of the most influential models was proposed by Walt W. Rosтow (1971), that combines economic (productivity, investments, knowledge), demographic (mobility), political (role of the state) and socio-cultural factors to identify five stages of economic growth: traditional society, 
transition to take-off, take-off, maturity and high mass consumption epochs.

Certain economic sectors are dominant in each stage, and the take-off is driven by industrialisation. Whereas, John Friedmann's (1973) four-stage core-periphery development model (preindustrial, incipient industrial, advanced industrial and post-industrial stages) suggests a clearer spatial accent, assuming that each stage of development corresponds to a certain type of spatial structure (SCHÄTZL, L. 1998). In his model, the spatial structure evolves from an initial equilibrium situation - with a high level of isolation between settlements and a low level of spatial interactions - into a complex spatial structure, with a high level of functional interdependencies between the core and the peripheral regions. In the fourth stage of development, a new spatial equilibrium emerges characterised by low level of regional inequalities.

The four-stage model developed by Harry W. RichaRdson (1973) rests on a similar logic; nevertheless, this concept is more complex and introduces the idea of reverse polarisation. It attaches the decentralisation process of economic activities in the third stage of economic development, when investments and population migration are oriented from the core regions to the centres of the peripheries, producing a more balanced urban and regional structure (SCHётZL, L. 1998).

It is obvious that historical approaches have contributed largely to the regional inequality debate, by combining a large number of economic, social and institutional factors and also by offering an alternative narrative to the formalised neoclassical models. Moreover, these models combine the time and space dimensions, re-interpreting the processes described otherwise in the formal models, such as spatial diffusion, agglomeration and concentration.

The latter processes can be explained by the concepts of polarisation and depolarisation, as they appear in the four-stage model of Richardson. Nevertheless, detailed analysis of the above concepts revealed their weak points, such as their descriptive character, the linear, one-way logic of economic development - that limits their explanatory power on economic decline and crisis - and the lack of empirical findings on the final (equilibrium) stages of development characterised by declining regional inequalities.

\section{Theories of economic and spatial polarisation}

The theories of polarisation include the seminal works of Gunnar Myrdal (1957), Albert O. Hirschman (1958), Francois Perroux (1950), Nicholas Kaldor (1957) and the later developments of these theories, i.e. the concepts of development poles and the core-periphery models. Unlike the neoclassical theories, the theories of polarisation consider interregional inequalities growing, since the development advantages created in a region have a cumulative character determining the spatial and sectoral polarisation of socio-economic development. This cumulative process is triggered by the change of independent economic variables like the demand, income, investments or production (SснӓтZL, L. 1998).

The change of one variable induces a change of other variables, generating a cumulative process of polarisation. Thus, the equilibrium analysis specific to neoclassical theories was replaced by the concept of circular cumulative causation, introduced first by Myrdal (1957) and Kaldor (1957). According to this concept, the intensity of interregional inequality is determined by the intensity of two effects: the backwash effects through the migration of mobile production factors (labour, capital) from the peripheries to the core regions, and the spread effects emanating from the spatial diffusion of innovation, production and services from the core regions toward the peripheries.

Generally, the backwash effects are more intensive than the spread ones, which generates growing inequality tendencies. Exceptions are represented by the core economies where inequalities are decreasing due to the development of infrastructure and communication. 
The other basic assumption of polarisation theories is that polarised development is generated by the unequal regional distribution of growth factors (labour, capital, technology, infrastructure, investment and consumption functions, natural resources) and by the limited mobility of such factors. The concept suggests that relations emerging between core regions and peripheries are characterised by strong dependence and the economic growth of cores is possible only at the expense of the peripheries.

Later, the concept of growth poles was developed further by Perroux (1988) and by Jacques-Raoul Boudeville and José Ramón LAsuÉn (SchäTzL, L. 1998). Their key assumption is that the growth poles are urban centres which polarise a larger region, where a single major firm or an economic sector generates a growth process and interregional inequalities. As a consequence, the latest approaches to the growth poles adopted the idea of sectoral polarisation that leads to regional polarisation and to the establishment of spatial growth centres. The intensity of polarisation effects depends on the market share and on the size of the dominant economic sector. The factors for the concentration of development in growth poles are related to the localisation advantages of production factors. The possibility of spatial diffusion of growth towards peripheries is admitted.

An important contribution to the polarisation theories came from LAsuéN, J.R. (1973) who argued for that the explanation of unequal economic development can be reduced to the unevenly distributed technological innovation process (diffusion and adaptation). This process has two components: a temporal one, represented by sectoral innovation poles, and a spatial one, represented by urban poles. These two poles are strongly interconnected, thus, the urban network determines the differentiation of the innovation process concentrated in a relatively small number of urban agglomerations of the advanced economies. Meanwhile, innovation in non-core economies and in smaller urban centres rests on external development fac- tors and on adoption through imitation or diffusion. The intensity of adoption depends on the innovation capacity of the regional or urban economy that reinforces spatial concentration and polarisation.

The main weaknesses of polarisation theories lie in their rigid framework and the lack of explanatory power of historical turning points in regional development (KüHN, M. 2015).

The core-periphery models of world-system theories and the dependency theories add a power dimension to the relations of cores and peripheries (FrIEDMANN, J. 1973; WALLERSTEIN, I. 1974). According to these theories, the core regions (or countries) are innovative, play an active role in the international trade, export capital, produce high incomes, have high productivity and a stable political system. In contrast, peripheries are less innovative, they depend on capital import, have a minor role in international trade, low incomes and productivity, and they are unstable politically. As a consequence, peripheries are dependent on the centres and disadvantaged by unequal terms of trade.

WALLERSTEIN distinguishes semi-peripheries that are economies with both characteristics of the core and also of the periphery (Wallerstein, I. 1974). Semi-peripheries experience the highest mobility, and their prospective ascension to the status of a core region is determined by state interventions. The proponents of these theories do not consider the elimination of spatial inequalities by any development policy. From a geographic point of view, the above mentioned global core-periphery model can be identified at sub-national scale as well, emerging as a North-South divide (UK, Italy) or West-East disparities (Hungary, China, Germany), depending on national factors.

The weak point of the core-periphery models is represented by their strong focus on conflicting relations between centres and peripheries, reduced to a simple dualism of a powerful centre and a weak periphery (KüHN, M. 2015). Nonetheless, the theories of polarisation offer a relevant theoretical framework for the analysis of regional in- 
equalities. Their core-periphery concept is a useful analytical concept for the description of the spatial outcomes of polarisation processes, and their central idea of growing interregional inequalities corresponds to the main empirical findings.

New approaches to unequal development and growth

The new economic geography (NEG), grounded by Paul Krugman and developed by a range of economists and economic geographers during the last two decades offers a new perspective on the mechanism of unequal regional development, based on the agglomeration process of industrial activities. NEG uses the new trade theory introduced by Alfred Marshall (external economies, agglomeration), and two modelling techniques such as the Dixit-Stiglitz model of monopolistic competition and the iceberg function (Krugman, P.R. 1991).

According to the NEG's two-region model, a core-periphery structure evolves that determine their relationships: one of the regions ends up as an industrial core region, the other region becomes an agricultural periphery. The central element of the model is the mobility of manufacturing workers determined by interregional wage differentials. This induces a process of cumulative causation in the region with higher wages, where additional workers attract more firms as a result of increasing demand, which in turn attracts more workers from the periphery. This cumulative process might come to an end in two ways:

- First, if the centripetal (agglomeration) forces (market size, mobility of workers, positive external effects) are dominant, it results in a cumulative-circular, divergent and asymmetric development model, with one region achieving the core status, while the other becoming periphery.

- Second, if the centrifugal (dispersion) forces (immobile factors, e.g. natural resources, negative external effects, competition) are dominant, a regional convergence model prevails with low interregional differences. Krugman (2011) considers three factors that can modify the relation between centripetal and centrifugal forces:

a) economies of scale in industrial production,

b) transportation costs, and

c) demand for industrial goods.

The traditional growth models were seriously challenged by the endogenous (new) growth theories represented by Paul R. Romer, Robert Lucas, Robert J. BARro and Xavier SAla-I-Martin in the 1980s. Technological progress was considered as an endogenous growth factor (determined by R\&D, advanced education facilities etc.) by them, playing a central role in economic growth through increasing returns. As a consequence, the endogenous growth theories offer a picture with growing inequalities and economic divergence, where the driving factor is represented by the spatial concentration of knowledge and the spill-over effects generated by R\&D (Romer, P.M. 1986).

New growth theories pay much attention to the theory developed by Romer, which brings a novelty by considering monopolistic technological knowledge and imperfect market conditions. Another novelty was added to the debate by considering the dispersion effects resulting from industrial research. These dispersion effects are considered a major factor of technological development, in contrast to other new growth theories that propose different factors, like competences obtained by practice ('learning by doing'), or the dispersion effects resulted from capital investment (Ács, J.Z. and VArgA, A. 2000). Nevertheless, the lack of spatial dimension in new growth theories has limited their adaptation in economic geography (STERNBERG, R. 2001).

New concepts in this field explain regional convergence or divergence and regional differences by factors like the differences in the human capital, increasing returns, learning effects, firm agglomeration, interregional knowledge transfers and in innovation diffusion.

Recent studies added a further dimension to classical convergence studies by including the questions of income distribution and 
the growth rates of income (TsELIOS, V. 2009; Amarante, V. 2014; Castells-Quintana, D. and Royuela, V. 2014). For example, as Tselios (2009) suggested, there is a convergence not just in the growth rate of income, but also in growth rates of income inequalities. Moreover, while earlier concepts relied on macroeconomic variables (e.g. GDP per capita), recent studies have adopted a new microeconomic dimension (Tselios, V. 2009; Rodríguez-Pose, A. and Tselios, V. 2015), based upon household income data from the European Community Household Panel (ECHP). Generally, the lack of adequate regional data on household and individual income is one of the main reasons for the dominance of the macroeconomic approach.

It is a crucial question, because economic growth measured by GDP per capita has no relevance at individual scale, even though, the income distribution affects regional growth (Easterly, W. 2001; Dollar, D. and KraAy, A. 2002; Ezcurra, R. 2007; RodríGueZPose, A. and Tselios, V. 2010). Even more intriguing is the fact that empirical studies show convergence in incomes, in contrast to GDP per capita changes in Europe (EzcuRRA, R. and Pascual, P. 2005; Tselios, V. 2009).

Furthermore, recent studies introduced new concepts in the economic convergence/ divergence debate and suggest that regional inequalities have a cyclical evolution: phases of growing inequalities and divergence are followed by phases of declining inequalities and convergence. However, according to QUAH, D.T. (1996), economic growth and convergence are related, but they are logically distinct processes. It means that one can occur without the other (QUAH, D.T. 1996).

An important dimension of the regional convergence debate is the role of spatial interaction effects, geographical location and proximity disregarded in the neoclassical convergence studies. Regions are open to a range of economic and demographic flows, like knowledge spill-over, interregional trade, capital mobility, spatial mobility (migration and commuting); moreover, other types of regional spill-over and their effect cannot be neglected, as they are important factors of regional growth. Spatial spill-over affect the economic growth strongly, while the convergence process is different across spatial regimes (ERTur, C. et al. 2006). Therefore, spatial autocorrelation cannot be eliminated from the growth models without the risk of imposing serious restrictions to the model. Thus, we should not overlook spatial effects across borders and the spatial structures within regions.

In growth theories, the concept of polarisation is used to describe processes of spatial concentration of economic growth. Thus, polarisation should be considered a special case of economic divergence, moreover, the process of polarisation - the concentration of economy (and population) in certain urban centres - is contributing decisively to the production and reproduction of core-periphery structures.

A new approach in the convergence studies has been suggested by SALA-I-MARTIN, who found a slow convergence inside the group of developed countries (SALA-I-Martin, X. 1996). This finding was reinforced by other studies, and, as a consequence, a new approach has been developed called club convergence (BAumol, W.J. 1986; Quah, D.T. 1995). Its key argument is that the convergence occurs inside of groups of countries or sub-national regions (convergence clubs), while the inequalities between the groups (clubs) have a growing tendency.

This process is described as polarisation emphasising the spatial clustering (concentration process) of economic growth and it is viewed as a different phenomenon from inequality. Accordingly, regional polarisation is estimated by considering density functions for the distribution of GDP per capita. Important empirical evidence was brought for the existence and persistence of regional polarisation in the form of convergence clubs at the top and bottom of income distribution, while the middle-class clubs are vanishing (Quah, D.T. 1997; Castro, J.W. 2003; Sметкоwsкi, M. and Wójсік, P. 2012). Another major contribution of this new approach is the possibility of multiple equilibrium and 
steady-states to which similar economies converge. However, empirical studies in club convergence have brought new evidence that poorer regions are trapped in clubs or, with other words in a group of regions at a lower level of development and with no chances of a way out (Mora, T. 2005; BENEDEK, J. and KocZISZKY, Gy. 2015).

\section{The evaluation of different theoretical approaches on inequalities}

In this section, we argue that the abovediscussed theoretical approaches can be grouped according to key assumptions and findings (Table 1).

1. A group of approaches largely relies on hard production factors (capital, labour, technological progress) in explaining the evolution of regional economic inequalities. The traditional growth theories (neoclassical, post-Keynesian and the export base theories), the new growth theories and the NEG constitute this group. In these approaches multiplier effects - generated by investments, imports or exports - contribute to growth transmission largely and to amplifying inequalities. The weak points of these theories are related to their assumption of economic equilibrium and also the imperative of a rational and balanced spatial distribution of economy as there is no equilibrium situation, in which the interests of each economic actor are considered (Plummer, P.S. 2000). Thus, development and growth cannot be equal in all regions, and the steady-state situations are relative and unstable. Finally, the idea of long-term convergence of growth and inequalities between countries and sub-national regions was refuted by empirical studies.

2 . The second group of approaches - historical and sociological theories - embraced non-economic or 'soft' factors in their explanations for regional inequalities, such as the availability of services, quality of housing, accessibility, regional structure, characteristics of local or regional markets, the role of local administration, quality of life, quality of workforce. This group fills the gap opened up by quantitative models relying on 'hard' development factors, which cannot explain the diversity of regional development paths satisfactorily. They focus largely on the local perspective of development in which, the region appears as a strong entity with endogenous capacities for growth. Their weak point is related to the multi-stage de-

Table 1. Theoretical approaches to regional inequalities in comparison

\begin{tabular}{l|l|l|l}
\hline Group of theories & \multicolumn{1}{|c|}{$\begin{array}{c}\text { Theoretical } \\
\text { approach }\end{array}$} & $\begin{array}{l}\text { Tendency } \\
\text { of regional } \\
\text { inequalities }\end{array}$ & \multicolumn{1}{c}{$\begin{array}{c}\text { Reasons for increasing/diminishing } \\
\text { inequalities }\end{array}$} \\
\hline $\begin{array}{l}\text { Traditional models } \\
\text { of economic growth }\end{array}$ & $\begin{array}{l}\text { Neoclassic } \\
\text { Post-Keynesianism } \\
\text { Export base }\end{array}$ & $\begin{array}{l}\text { Diminishing } \\
\text { Diminishing } \\
\text { Diminishing }\end{array}$ & $\begin{array}{l}\text { Production factor mobility and diminishing } \\
\text { marginal product of capital } \\
\text { Multiplier effects, spatial effects of investments } \\
\text { Export activities }\end{array}$ \\
\hline Sociological theories & $\begin{array}{l}\text { Social inequality and } \\
\text { marginalisation }\end{array}$ & Growing & $\begin{array}{l}\text { Capitalism, new international division of } \\
\text { labour, the logic of capital accumulation }\end{array}$ \\
\hline $\begin{array}{l}\text { Historical theories } \\
\text { nomic and spatial } \\
\text { polarisation }\end{array}$ & $\begin{array}{l}\text { Historical approaches } \\
\text { Wolarisation } \\
\text { dependency }\end{array}$ & $\begin{array}{l}\text { Diminishing } \\
\text { Growing } \\
\text { Persisting or } \\
\text { growing }\end{array}$ & $\begin{array}{l}\text { Reversed polarisation, integration } \\
\text { Polarisation effects, position in the world } \\
\text { economy }\end{array}$ \\
\hline $\begin{array}{l}\text { New theories on } \\
\text { unequal develop- } \\
\text { ment and growth }\end{array}$ & $\begin{array}{l}\text { Endogenous growth } \\
\text { New economic } \\
\text { geography }\end{array}$ & $\begin{array}{l}\text { Persisting or } \\
\text { growing } \\
\text { Persisting or } \\
\text { growing }\end{array}$ & $\begin{array}{l}\text { Regional concentration of knowledge and } \\
\text { technology } \\
\text { Transport costs, spatial concentration of } \\
\text { industry, mobility of industrial workforce }\end{array}$ \\
\hline
\end{tabular}

Source: Authors' own compilation. 
velopment model which should be passed by every region in order to obtain a higher development status. For this, the model cannot explain deviations from this general trend generated by structural factors (differences in the internal structure of the regions), historical paths (historical accidents) or by different regional adaptation capacities.

3 . The third group of approaches is represented by polarisation, world-system, and dependency theories representing a structuralist position, as they place cores and peripheries in the context of a globally overarching system. They are anchored in global processes, where the macroeconomic and political structures and the positioning of the region in the historically emerged core-periphery system determine regional development. Thus, the conditions of economic growth for peripheral regions are defined by the domination of core regions resulting in a core-periphery international division of labour with different rates of accumulation.

Summarising the reviewed literature, we can conclude the followings:

- Polarisation is linked to the complementary notion of convergence/ divergence;

- It is focused on space-dynamics, where some regions rise while others fall;

- These processes are shaped by economic and social dimensions;

- Polarisation has varying characteristics on different spatial scales, from global to local.

We think, the discussed concepts of polarisation and convergence/divergence provide arguments for a more comprehensive and interdisciplinary approach in researching spatial inequalities. Like polarisation, the concept of convergence can be viewed as a multi-dimensional process that can be explained as the interaction of economic and social dimensions. The new approach we propose should include the combination of the concepts of polarisation and convergence/ divergence and provide a framework for the operationalisation for the empirical research using the tools offered by spatial econometrics. In recent studies (BENEDEK, J. and Kocziszky, Gy. 2015; BenedeK, J. et al. 2015), new evidence was provided, that economic and social development in CEE is going hand in hand with growing regional inequalities and polarisation. In addition, the peripheral regions of the CEE at sub-national level seem to be trapped in the 'convergence clubs' of backward regions diverging from the group of economically dynamic regions.

We think, further research in this field can contribute to a more comprehensive understanding of polarisation and peripheralisation from a quantitative perspective. However, it is necessary to define the main economic and social dimensions, and to identify the main factors determining polarisation.

Some of the latest studies are also going in this direction (Duro, J.A. 2008; Liargovas, P. and Foторoulos, G. 2009; Sметкоwsкi, M. and Wóscik, P. 2012; Tselios, V. 2014; Li, G. and FAnG, C. 2014; Rodríguez-Pose, A. and Tselios, V. 2015; Royuela, V. and García, G.A. 2015), proposing a new concept of convergence/divergence, interpreting them as multi-dimensional processes. This contrasts with the established neoclassical and endogenous growth theories still operating with a one-dimensional economic convergence concept.

The multi-dimensional approach to convergence/divergence reflects upon some of the concerns formulated in recent years and reacting to the inadequacy of the concepts and of the instruments used for the measuring regional inequalities - which are still based on the economic dimension of development. Thus, there is a growing recognition of the need for including the social dimension in the analysis of regional inequalities expressing people's desire for a better quality of life and social welfare. The question is highly relevant to the regional policy of the EU, trapped in a simplistic GDP per capita approach to delimiting the regions 'lagging behind', largely neglecting the basic interests of local, regional or even national communities.

One can observe that economic growth often has no significant influence on the income of the households and on the improvement of the social indicators expressing the 
quality of life (EASTERLY, W. 1999; RodríGUEZPose, A. and Tselios, V. 2015). Nevertheless, the research conducted by BECKER, G.S. et al. (2005) showed that the income and health inequality trends are decupled at a global scale: while income disparities have a growing tendency, cross-country inequality in different dimensions of health is diminishing (BECKer, G.S. et al. 2005). This suggests that social convergence can occur without economic convergence. At the same time, it calls for a regional social policy beside the existing regional policy.

The studies reviewed above refer to a multi-dimensional convergence process at cross-country level and propose a new and alternative methodology for the analysis of convergence and divergence processes. Rodríguez-Pose, A. and Tselios, V. (2015) used Sen's index of social welfare in the European context, while other studies proposed a large set of social indicators for the analysis of social disparities at international level. For instance, more and more the social and demographic components of Human Development Index (e.g. life expectancy, infant mortality, educational enrolment, or the literacy rate) are used to contribute to international comparative studies.

Moreover, studies based on micro level (personal or household) data give accounts of the processes of social convergence in Europe, e.g. Rodríguez-Pose, A. and Tselios, V. (2015), who used microeconomic data of the European ECHP in their analysis. Their main question was whether the absence of a strong convergence in GDP per capita in the EU makes the convergence in social welfare also weak or absent. They have found major social welfare disparities between different regions of Europe, including a clear northernsouthern divide. Welfare levels in the southern periphery - covering Greece, Southern Italy, Spain, and Portugal - are typically half of the EU average. In general, regions with similar welfare levels cluster together.

The above methodological innovations provided an empirical contribution to the work of "The Commission on the Measurement of
Economic Performance and Social Progress" that defined the concept of well-being considering the following dimensions: material living standards (income, consumption, wealth), health, education, political representation and governance, social and personal connections, environment, economic and physical insecurity (Stiglitz, J. et al. 2010).

Concerning the results of multi-dimensional convergence studies, there are some important remarks that have to be made. Methodological shortcuts are inevitable, like in the case of one-dimensional studies, which means that the results are highly dependent on the period under research, on the geographical scale and on the used indicators. While the international comparison proved a strong connection between the economic and the social convergence, studies focused on sub-national/regional scale revealed the opposite situation: social convergence has occurred without economic convergence (Rodríguez-Pose, A. and Tselios, V. 2015; Royuela, V. and García, G.A. 2015). It is worth to consider this last issue, as it suggests that living standards can be improved even in the absence of economic growth or economic convergence. It is in this direction that the "The Commission on the Measurement of Economic Performance and Social Progress" has formulated as one of its key messages: "...the time is ripe for our measurement system to shift emphasis from measuring economic production to measuring people's well-being." (Stiglitz, J. et al. 2010, p. 312).

\section{Conclusions and future prospects}

We can summarise our contribution to the question of convergence and polarisation around two ideas.

1. First, our paper argues that alternative interpretations of convergence are possible, and that this concept can be related to other theoretical approaches than growth theories. Moreover, we have argued for the multidimensional perspective of convergence and divergence that means the combination of 
social and economic dimensions is needed to understand the interrelatedness of social and economic factors influencing development. This new approach would enable a more proper operationalisation of the technological factor, taking into account the fact that the reduction of the technological gap needs not only good imitation strategies, but also the development of social capabilities. In addition, the multidimensional approach can properly integrate the contributions of sociology studies focused on the question of social inequalities and social polarisation at the micro scale. They contribute to the rescaling of the research by concentrating on the households as basic research units. This rescaling was strongly supported by the proponents of recent microeconomic studies on household level income inequalities as well. We think, the definition of social polarisation in sociology (as the shrinkage of the middle class) can be adopted in the economic approaches as well and interpreted as the shrinkage process of semi-peripheries. BAUMoL's (1986) idea on convergence clubs strengthens this fact, bringing evidence for a vanishing middle category club, while richer regions are becoming even richer and the poorest ones poorer.

2. Second, we have raised arguments to prove that processes like convergence, divergence, economic growth, spatial mobility and innovation are strongly interrelated. As we mentioned in the introductory part, the concept of polarisation describes the spatial concentration of economic activities and population. At a high intensity of the concentration, core-periphery structures are reinforced, as the core regions attract more capital and population, while peripheries are shrinking both in economic and demographic terms. Thus, polarisation leads to increasing divergence, and this way, to increasing regional inequalities. The opposite process happens when capital and population spreads to peripheries, leading to convergence and diminishing regional inequalities, a process which can be termed as "depolarisation" (an antithesis of polarisation).

However, we have pointed out that economic growth and convergence are not neces- sarily interrelated, since one can occur without the other. Research on the links between these processes needs more attention in the future. Growth increases economic output and decreases income inequality, but we do not know if the growth in poorer and highinequality economies would lead to catching up with the richer ones (Tselios, V. 2009). All this shows that convergence is a basic concept which reflects on polarisation, regional inequalities, and income distribution.

As suggested by various theoretical approaches (NEG, polarisation theory), we think, there is a need to drive the future attention toward the impact of territorial mobility in both the core and the peripheral regions. We have two major reasons to do so. First, due to the fact that significant financial and political efforts have been made to provide certain public services in remote areas, the focus of the analysis should be on how the spatially differentiated migration processes affect the population thresholds necessary to assure public services like education, health care etc. Second, the focus of future studies should be on the agglomeration effects generated by the migration processes in core regions, such as the capital or the regional urban centres - revealing the turning points at which, population agglomeration is not able to generate positive effects anymore and is likely to turn into dispersion.

\section{REFERENCES}

Ács, J.Z. and VArga, A. 2000. Térbeliség, endogén növekedés és innováció. (Geography, endogeneous growth and innovation). Tér és Társadalom 14 (4): 23-38.

AmARAnte, V. 2014. Revisiting Inequality and Growth: Evidence for Developing Countries. Growth and Change 45. (4): 571-589.

Barro, R.J. and Sala-I-Martin, X. 1995. Economic Growth. New York, McGraw-Hill, 539 p.

Baumol, W.J. 1986. Productivity Growth, Convergence, and Welfare: What the Long-Run Data Show. American Economic Review 76. (5): 1072-1085.

Becker, G.S., Philipson, T.J. and Soares, R.R. 2005. The Quantity and Quality of Life and the Evolution of World Inequality. American Economic Review 95. (1): 277-291. 
Beneder, J. 2004. Amenajarea teritoriului i dezvoltarea regională. (Spatial planning and regional development) Cluj-Napoca, Presa Universitară Clujeană, $310 \mathrm{p}$.

Benedek, J. and Kocziszky, Gy. 2015. Paths of Convergence and Polarisation in the VisegrádCountries. In Understanding Geographies of Polarization and Peripheralization. Eds.: LANG, T., Henn, S., Ehrlich, K. and Sgibnev, W. Basingstoke, Palgrave/MacMillan, 00-00.

BenedeK, J., Cristea, M. and Szendi, D. 2015. Catching Up or Falling Behind? Economic Convergence and Regional Development Trajectories in Romania. Forthcoming in Romanian Review of Regional Studies 11.

Bond, P. 1999. What is Uneven Development?. In The Encyclopedia of Political Economy. Ed.: O'Hara, P. London, Routledge, Available at: http://www. marxmail. org/faq/uneven_development.htm. Last accessed on 10.06.2015.

Castells-Quintana, D. and Royuela, V. 2014. Agglomeration, Inequality and Economic Growth. Annals of Regional Science 52. (2): 343-366.

Castro, J.W. 2003. Regional Convergence, Polarisation and Mobility in the European Union, 1980-1996. Journal of European Integration 25. (1): 73-86.

Copus, A. 2014. TiPSE - The Territorial Dimension of Poverty and Social Exclusion in Europe. Final Report, Part B Main Report. Available at: http://www.espon. eu/main/Menu_Projects/Menu_AppliedResearch/ tipse.html?currentPage=2\&pagination=previous . Last accessed on 23.02.2015

Dollar, D. and KraAY, A. 2002. Growth Is Good for the Poor. Journal of Economic Growth 7. (3): 195-225.

Domar, E.D. 1946. Capital Expansion, Rate of Growth, and Employment. Econometrica 14. (2): 137-147.

Duro, J.A. 2008. Cross-country Inequalities in Welfare and Its Decomposition by Sen Factors: The Virtues of the Theil Index. Applied Economics Letters 15. (13): 1041-1045.

EAPN 2014. Poverty and Inequality in the EU. EAPN Explainer \#6. European Anti-Poverty Network. Available at: http://povertyalliance.org/userfiles/ files/2014-Poverty -Explainer-EN-web.pdf. Last accessed on 10.02.2015.

EAsterly, W. 1999. Life During Growth. Journal of Economic Growth 4. (3): 239-276.

Easterly, W. 2001. The Middle Class Consensus and Economic Development. Journal of Economic Growth 6. (4): 317-335.

EC 2004. A New Partnership for Cohesion: Convergence, Competitiveness, Cooperation. Third Report on Economic and Social Cohesion. Luxembourg, Office for Official Publications of the European Communities.

EC 2007. Growing Regions, Growing Europe. Fourth Report on Economic and Social Cohesion. Luxembourg, Office for Official Publications of the European Communities.
EC 2010. Investing in Europe's Future. Fifth Report on Economic, Social and Territorial Cohesion. Luxembourg, Office for Official Publications of the European Communities.

EC 2014. Investment for Jobs and Growth. Sixth Report on Economic, Social and Territorial Cohesion. Luxembourg, Office for Official Publications of the European Communities.

Ertur, C., Le Gallo, J. and Baumont, C. 2006. The European Regional Convergence Process, 19801995: Do Spatial Regimes and Spatial Dependence Matter? International Regional Science Review 29. (1): 3-34.

Ezcurra, R. 2007. Is Income Inequality Harmful for Regional Growth? Evidence from the European Union. Urban Studies 44. (10): 1953-1971.

Ezcurra, R. and Pascual, P. 2005. Is There Convergence in Income Inequality Levels among the European Regions? Applied Economics Letters 12. (12): 763767.

FAgerberg, J. 1995. Convergence or Divergence? The Impact of Technology on "Why Growth Rates Differ". Journal of Evolutionary Economics 5. (3): 269-284.

FriedmanN, J. 1973. A theory of polarised development. In Urbanisation, Planning, and National Development. Ed.: Friedmann, J. Beverly Hills, Sage, 41-67.

Gerschenkron, A. 1962. Economic Backwardness in Historical Perspective, a Book of Essays. Cambridge, MAS, Belknap Press of Harvard University Press, $468 \mathrm{p}$.

Gottdiener, M. and Budd, L. 2005. Key Concepts in Urban Studies. London, Sage Publications, 188 p.

Hamnett, C. 2001. Social Segregation and Social Polarisation. In Handbook of Urban Studies. Ed.: PAdDison, R. London, Sage Publications, 162-176.

Harrod, R.F. 1939. An Essay in Dynamic Theory. The Economic Journal 49. (193): 14-33.

Harvey, D. 1996. Justice, Nature and the Geography of Difference. Oxford, Blackwell, $480 \mathrm{p}$.

Hirschman, A.O. 1958. The Strategy of Economic Development. New Haven, Yale University Press, $230 \mathrm{p}$.

Kaldor, N. 1957. A Model of Economic Growth. Economic Journal 67. (268): 591-624.

KeIM, K.D. 2006. Peripherisierung ländlicher Räume Essay. Available at: http://www.bpb.de/apuz/29544/ peripherisierung-laendlicher-raeume-essay? $\mathrm{p}=$ all. Last ac-cessed on 25.03.2015.

Korzeniewicz, R.P. and Albrecht, S. 2013. Thinking globally about inequality and stratification: Wages across the world, 1982-2009. International Journal of Comparative Sociology 53. (5-6): 419-443.

Kreckel, R. 2004. Politische Soziologie der sozialen Ungleichheit. Frankfurt, Campus, 412 p.

Krugman, P.R. 1991. Geography and Trade. Cambridge, MIT Press, 156 p. 
Krugman, P.R. 2011. The New Economic Geography, Now Middle-Aged. Regional Studies 45. (1): 1-7.

KüнN, M. 2015. Peripheralisation: Theoretical Concepts Explaining Socio-Spatial Inequalities. European Planning Studies 23. (2): 367-378.

LANG, T. 2012. Shrinkage, Metropolisation and Peripheralisation in East Germany. European Planning Studies 20. (10): 1747-1754.

Lang, T., Henn, S., Ehrlich, K. and Sbignev, W. 2015. Introduction. Forthcoming. Understanding New Geographies of Central and Eastern Europe. Socio-Spatial Polarisation and Peripheralisation in a Rapidly Changing Region. Basingstoke, Palgrave Macmillan,

LAsuÉN, J.R. 1973. Urbanisation and Development. The Temporal Interaction between Geographical and Sectoral Clusters. Urban Studies 10. (2): 163-188.

Lefèbvre, H. 1991. The Production of Space. Blackwell, Oxford, $464 \mathrm{p}$.

LI, G. and FANG, C. 2014. Analyzing the MultiMechanism of Regional Inequality in China. Annales of Regional Science 52. (1): 155-182.

Liargovas, P. and Fotopoulos, G. 2009. Socioeconomic Indicators for Analyzing Convergence: The Case of Greece: 1960-2004. Social Indicators Research 93. (2): 315-330.

Maestri, V. 2015. A Measure of Income Poverty Including Housing: Benefits and Limitations for Policy Making. Social Indicators Research 121. (3): 675-696.

Malecki, E.J. 1997. Technology and Economic Development. Harlow, Longman, 460 p.

Mankiw, N.G., Romer, D. and Weil, D.N. 1992. A Contribution to the Empirics of Economic Growth. Quarterly Journal of Economics 107. 407-437.

Massey, D. 1990. American Apartheid: Segregation and the Making of the Underclass. The American Journal of Sociology 96. (2): 329-357.

Mollenkopf, J. and Castells, M. 1991. Dual City: Restructuring New York. New York, Russell Sage Foundation, 492 p.

Mora, T. 2005. Evidencing European Regional Convergence Clubs with Optimal Grouping Criteria. Applied Economics Letters 12. (15): 937-940.

Myrdal, G. 1957. Economic Theory and Underdeveloped Regions. London, Gerald Duckworth, 168 p.

North, D. 1955. Location Theory and Regional Economic Growth. Journal of Political Economy 63. (3): 243-258.

Perroux, F. 1950. Economic Spaces: Theory and Application. Quarterly Journal of Economics 64. (1): 89-104.

Perroux, F. 1988. The Pole of Development's New Place in a General Theory of Economic Activity. In Regional Essays in Honor of Francois Perroux. Eds.: Higgins, B. and Savoie, D.J. Boston, Unwin Hyman, 48-76.
Plummer, P.S. 2000. The Modeling Tradition. In $A$ Companion to Economic Geography. Eds.: ShepPard, E. and BArnes, T.J. Oxford, Blackwell, 27-40.

QuaH, D.T. 1995. Regional Convergence Clusters Across Europe. Centre for Economic Performance Discussion Paper, Nr. 274. Available at: [http://cep. lse.ac.uk/pubs/download/DP0274.pdf], last accessed on 18.06.2015.

Quah, D.T. 1996. Empirics for Economic Growth and Convergence. European Economic Review 40. (6): 1353-1375.

QuAH, D.T. 1997. Empirics for Growth and Distribution: Stratification, Polarisation, and Convergence Clubs. Journal of Economic Growth 2. (1): 27-59.

Richardson, H.W. 1973. Regional Growth Theory, London, Macmillan.

Rodríguez-Pose, A. and Tselios, V. 2010. Inequalities in Income and Education and Regional Economic Growth in Western Europe. Annals of Regional Science 44. (2): 349-75.

Rodríguez-Pose, A. and Tselios, V. 2015. Toward Inclusive Growth: Is There Regional Convergence in Social Welfare? International Regional Science Review 38. (1): 30-60.

Romer, P.M. 1986. Increasing Returns and Longrun Growth. Journal of Political Economy 94. (5): 1002-1037.

Rostow, W.W. 1971. The Stages of Economic Growth. Cambridge, Cambridge University Press, 428 p.

Royuela, V. and García, G.A. 2015. Economic and Social Convergence in Colombia. Regional Studies 49. (2): 219-239.

SAlA-I-Martin, X. 1996. Regional Cohesion: Evidence and Theories of Regional Growth and Convergence. European Economic Review 40. (6): 1325-1352.

Sassen, S. 1991. The Global City: New York, London, Tokyo. Princeton, N.J., Princeton University Press, $480 \mathrm{p}$.

Schatz, H. and Venables, A.J. 2000. The Geography of International Investment, World Bank Policy Research Working Paper, Nr. 2338. Available at: [https://openknowledge.worldbank.org/bitstream/ handle/10986/18843/multi_page.pdf?sequence=1]. Last accessed on 18.06.2015.

SснӓтzL, L. 1998. Wirtschaftsgeographie 1. Theorie. F. Schöningh, Paderborn, 232 p.

Smetкowski, M. and Wójcik, P. 2012. Regional Convergence in Central and Eastern European Countries: A Multidimensional Approach. European Planning Studies 20. (6): 923-939.

Solow, R.M. 1956. A Contribution to the Theory of Economic Growth. Quarterly Journal of Economics 70. (1): 65-94.

Sternberg, R. 2001. New Economic Geography. Zeitschrift für Wirtschaftsgeographie 45. (3-4): 159-180.

Stiglitz, J., Sen, A. and Fitoussi, J.P. 2010. A Bizottság jelentése a gazdasági teljesítmény és a társadalmi 
fejlődés méréséröl (Report by the Commision on the measurement on economic performance and social progress). Statisztikai Szemle 88. 305-320.

Thiry, G. 2015. Beyond GDP: Conceptual Grounds of Quantification. The Case of the Index of Economic Well-Being (IEWB). Social Indicators Research 121. (2): 313-343.

Tselios, V. 2009. Growth and Convergence in Income per Capita and Income Inequality in the Regions of the EU. Spatial Economic Analysis 4. (3): 343-370.
Tselios, V. 2014. The Granger-Causality between Income and Educational Inequality: a Spatial CrossRegressive VAR Framework. Annals of Regional Science 53. (1): 221-243.

Wacquant, L. 2007. Territorial Stigmatisation in the Age of Advanced Marginality. Thesis Eleven 91. 66-77.

Wallerstein, I. 1974. The Modern World-System. Capitalist Agriculture and the Origins of the European World-Economy in the Sixteenth Century. New York, Academic Press, 410 p. 


\title{
Changing Ethnic Patterns of the Carpatho-Pannonian Area from the Late $15^{\text {th }}$ until the Early $21^{\text {st }}$ Century
}

\author{
Edited by: KÁroly KOCSIS and PATriK TÁTRAI \\ Hungarian Academy of Sciences, Research Centre for Astronomy and Earth Sciences \\ Budapest, 2013
}

This is a collection of maps that visually introduces the changing ethnic patterns of the ethnically, religiously, culturally unique and diverse Carpathian Basin and its neighbourhood, the Carpatho-Pannonian area.

The Hungarian and English volume consist of three structural units. On the main map, pie charts depict the ethnic structure of the settlements in proportion to the population based on census data et the millennium. In the supplementary maps, changes of the ethnic structure can be seen at nine dates (in 1495, 1784, 1880, 1910, 1930, 1941, 1960, 1990 and 2001). The third unit of the work is the accompanying text, which outlines the ethnic trends of the past five hundred years in the studied area.

The antecedent of this publication is the "series of ethnic maps" published by the Geographical Research Institute of the Hungarian Academy of Sciences from the middle of the 1990's, which displayed each of the regions of the Carpathian Basin (in order of publication: Transylvania, Slovakia, Transcarpathia, Pannonian Croatia, Vojvodina, Transmura Region, Burgenland, Hungary). This work represents, on the one hand, the updated and revised version of these

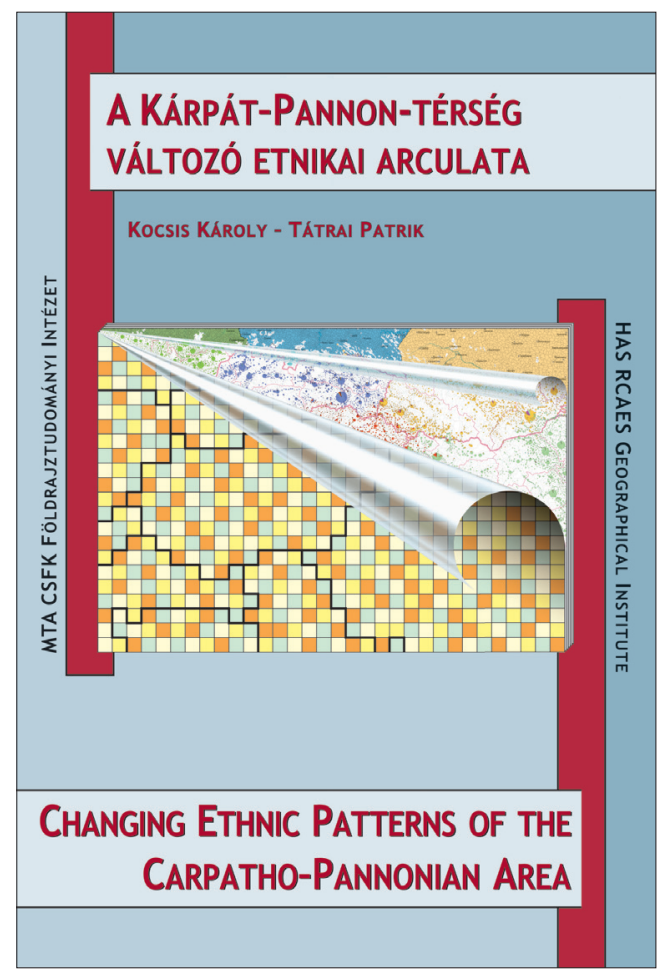
areas, and, on the other hand, regions beyond the Carpathian Basin not included on previous maps. Thus, the reader can browse ethnic data of some thirty thousand settlements in different maps.

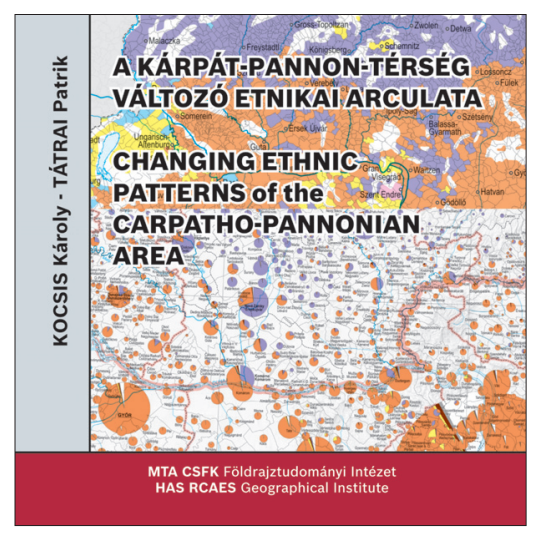

Price: EUR 12.00

Order: Geographical Institute RCAES HAS Library H-1112 Budapest, Budaörsi út 45.

E-mail: magyar.arpad@csfk.mta.hu 